\title{
Salmonella in free living terrestrial and aquatic turtles
}

\author{
J. Hidalgo-Vila ${ }^{\mathrm{a}, *}$, C. Díaz-Paniagua ${ }^{\mathrm{a}, *}$, C. de Frutos-Escobar ${ }^{\mathrm{b}}$, \\ C. Jiménez-Martínez ${ }^{b}$, N. Pérez-Santigosa ${ }^{a}$ \\ a Estación Biológica de Doñana, CSIC, Avda. María Luisa s/n, 41013 Sevilla, Spain \\ ${ }^{\mathrm{b}}$ Laboratorio Central de Veterinaria, Ministerio de Agricultura, Pesca y Alimentación, \\ Ctra. de Algete, Km 8, 28110 Algete, Madrid, Spain
}

\begin{abstract}
Detection of Salmonella in pet turtles has been the focus of extensive research, but its incidence in free living turtles is not well known. The aim of this study was to evaluate the incidence of Salmonella in terrestrial and aquatic species of chelonians inhabiting a National Park in southwestern Spain. Individuals of the terrestrial tortoise Testudo graeca $(\mathrm{n}=16)$ and the aquatic turtles Emys orbicularis $(n=26)$ and Mauremys leprosa $(n=50)$ were investigated. Maximum incidence of Salmonella was recorded in the terrestrial species (100\%). In contrast, the incidence of infected animals was low in the aquatic species, $12 \%$ in M. leprosa and $15.4 \%$ in E. orbicularis. Five serotypes of Salmonella belonging to subspecies enterica (I) and salamae (II) were identified. All serotypes were found in the terrestrial species, and three in the aquatic ones, suggesting that wild terrestrial chelonians are important reservoirs of Salmonella in our study area. Cloacal transmission during mating is the most probable mode of transmission among individuals.
\end{abstract}

Keywords: Salmonella; Salmonellosis; Free living chelonians; Transmission

\section{Introduction}

Salmonella commonly lives in the intestine of vertebrates, and has been frequently reported in reptiles (Chiodini and Sundberg, 1981; Millan et al., 1997; Mitchell and Shane, 2000; Abalem de Sá and

\footnotetext{
* Corresponding authors. Tel.: +34 954232340; fax: +34 954621125

E-mail addresses: judit@ebd.csic.es (J. Hidalgo-Vila), poli@ebd.csic.es (C. Díaz-Paniagua).
}

Solari, 2001; Geue and Löschner, 2002; Corrente et al., 2004; Mermin et al., 2004).

The incidence of Salmonella in turtles has been the focus of extensive research because of the common use of these animals as pets. In fact, pet turtles are frequently reported as responsible for salmonellosis in humans, especially in children (Feeley and Treger, 1969; Mermin et al., 1997; Woodward et al., 1997; Lynch et al., 1999; Torfoss and Abrahamsen, 2000; Rodgers et al., 2002). However, the incidence of Salmonella in free living reptiles is not well known (Ozsan et al., 1973; Greenberg et al., 1976; Wuthe 
et al., 1979; Bronikowski et al., 2001; Thomas et al., 2001; Briones et al., 2004).

In this study we analyse the incidence of Salmonella in free living individuals of three species of chelonians in southwestern Spain. The spur-thighed tortoise (Testudo graeca) is an herbivorous terrestrial species which is only occasionally seen in aquatic habitats where they feed on macrophytes (Andreu et al., 2000). The European pond turtle (Emys orbicularis) and the Mediterranean turtle (Mauremys leprosa) inhabit ponds, streams and other aquatic habitats, and they only move into terrestrial habitats to nest or to hibernate (Fritz, 2001). The aims of this study were to detect and quantify the presence of Salmonella in these free living reptiles, and to determine if the incidence is different in the terrestrial versus the aquatic species.

\section{Materials and methods}

During spring and early summer of 2003-2004, 16 adult tortoises (T. graeca) and 76 adult turtles (50 M. leprosa and 26 E. orbicularis) were captured in Doñana National Park (in southwestern Spain), a large coastal reserve characterized by sandy grounds and marshes.

After capture, every individual was housed singly in order to prevent Salmonella transmission among themselves. Because bacteria excretion is not continuous, for each individual three faecal samples (one on the day of capture, and the other two samples on subsequent days) were taken from the cloaca using cotton sterile swabs. They were stored at 4 8C in Stuart transport medium for 1-4 days before cultivation and identification of Salmonella isolates in the National Reference Laboratory for Animal Salmonellosis in Spain (Laboratorio Central de Veterinaria, Algete, MAPA).

Cultivation of bacteria was made according to ISO 6579: 2002, with addition of some culture media that have demonstrated good performance for these samples (doc ISO/TC34SC $9 \mathrm{~N}$ 681). Suspect salmonellae colonies were removed for identification by biochemical tests serological identification and serotyping was performed according to KaufmannWhite scheme (Kaufmann, 1966).

\section{Results}

Maximum incidence of Salmonella was recorded in the tortoises, as positive occurrence was found in all (100\%) individuals examined. In contrast, a low incidence of infected individuals was recorded in the turtles, being $12 \%$ in $\mathrm{M}$. leprosa and $15.38 \%$ in $\mathrm{E}$. orbicularis. The infection rate of the terrestrial turtle was significantly different from that of the aquatic turtles $\left(x^{2}=16.72\right.$, d.f. $\left.=1, p<0.0001\right)$, while the difference between the two species of aquatic turtles was not significant $\left(x^{2}=0.172\right.$, d.f. $\left.=1, p=0.679\right)$.

Table 1

Isolated serotypes of Salmonella in the three chelonian species

\begin{tabular}{|c|c|c|c|c|c|}
\hline Subspecies & Serotype & & Testudo graeca & Mauremys leprosa & Emys orbicularis \\
\hline \multirow[t]{2}{*}{ I } & Abony & $\mathrm{N}$ & 2 & - & - \\
\hline & & $\%$ & 12.5 & - & - \\
\hline \multirow[t]{2}{*}{ I } & Newport & $\mathrm{N}$ & 2 & - & - \\
\hline & & $\%$ & 12.5 & - & - \\
\hline \multirow[t]{2}{*}{ I } & Potsdam & $\mathrm{N}$ & 6 & 4 & 3 \\
\hline & & $\%$ & 37.5 & 66.6 & 75.0 \\
\hline \multirow[t]{2}{*}{ II } & $9,12: 1, \mathrm{v}: \mathrm{z}_{39}$ & $\mathrm{~N}$ & 1 & - & - \\
\hline & & $\%$ & 36.3 & - & - \\
\hline \multirow[t]{2}{*}{ II } & $9,12: 1, \mathrm{v}: \mathrm{Z}_{39}(\mathrm{NI})$ & $\mathrm{N}$ & 3 & 1 & 1 \\
\hline & & $\%$ & 18.8 & 16.6 & 25 \\
\hline \multirow[t]{2}{*}{ II } & 9,12:1,v:z $29: 1,5$ & $\mathrm{~N}$ & 2 & 1 & - \\
\hline & & $\%$ & 12.5 & 16.6 & - \\
\hline
\end{tabular}

Number and percentage of isolates. $(\mathrm{NI})=$ second phase flagellar antigen not identified. 
Twenty-six Salmonella isolates belonging to the species Salmonella enterica were obtained. No more than one serotype was isolated from individual animals. Seventeen isolates were included in subspecies enterica (I), in which we identified three serotypes. The remaining nine isolates belonged to subspecies salamae (II), with two serotypes identified and five isolates which could not be totally identified (Table 1).

T. graeca exhibited all serotypes described (identified and not identified), with Potsdam (I) being the most frequent (in $37.5 \%$ of isolates), and with lower frequencies of six isolates of subspecies salamae (II), two Abony (I) and two Newport (I) (Table 1).

The aquatic turtles showed lower diversity of serotypes, with Potsdam being the most frequent, as it was isolated in $66 \%$ of infected M. leprosa and in $75 \%$ E. orbicularis. Only two or one additional serotypes belonging to the subspecies salamae, were isolated in these species.

\section{Discussion}

Among reptiles, a high incidence of serotypes of Salmonella has been described in snakes and lizards (Greenberg et al., 1976; Wuthe et al., 1979; Mermin et al., 1997; Burnham et al., 1998; Abalem de Sá and Solari, 2001; Geue and Löschner, 2002; Corrente et al., 2004; Pasmans et al., 2005) while some chelonians have been considered with low or no prevalence (Ozsan et al., 1973; Abalem de Sá and Solari, 2001; Geue and Löschner, 2002; Pasmans et al., 2002; Corrente et al., 2004; Richards et al., 2004). In contrast, in European tortoises from captive centres, the incidence of Salmonella was found to be over $70 \%$ of individuals (Pasmans et al., 2000). A recent study reporting the incidence of Salmonella in wild and captive reptiles in Spain (Briones et al., 2004) revealed similar proportions in chelonians, saurians and ophidians. $\mathrm{M}$. leprosa and captive individuals of $\mathrm{T}$. graeca were included in this study and had infection rates of $0 \%$ and $31 \%$, respectively. A notably higher incidence of Salmonella was found in our study, as all tortoises were infected, and many of the turtles were Salmonella positive. The absence of infections in $\mathrm{M}$. leprosa from central Spain (reported in Briones et al., 2004) may be explained by the low number of individuals analysed in that study, as we found a low frequency of Salmonella in our population from Doñana National Park.

Tortoises may be considered as a very important reservoir for Salmonella in the study area. The most commonly reported serotypes responsible for human salmonellosis, Enteriditis or Typhimurium, were not isolated in our study. Nevertheless, the serotypes isolated have been previously reported in human salmonellosis (Chiodini and Sundberg, 1981; Woodward et al., 1997; Torfoss and Abrahamsen, 2000; Unicomb et al., 2003; Briones et al., 2004). Potsdam, the most frequent serotype isolated in this study, is not commonly found but it has been previously reported in reptiles (Burnham et al., 1998; Briones et al., 2004). Newport is widely distributed, and frequently reported in reptiles (Greenberg et al., 1976; Abalem de Sá and Solari, 2001; Geue and Löschner, 2002; Corrente et al., 2004) and in aquatic environment (Polo et al., 1999; Baudart et al., 2000). Abony has been previously isolated in tortoises (Pasmans et al., 2000) and rivers (Usera et al., 1999). Serotypes belonging to subspecies salamae (II) are common in ectothermic animals and in the environment (Abalem de Sá and Solari, 2001).

Salmonella survives well in the environment (Roszak et al., 1984; Polo et al., 1999; Baudart et al., 2000). In the wild, the ingestion of faeces or contaminated water is considered a probable way of colonization of Salmonella (Polo et al., 1999; Baudart et al., 2000; Mermin et al., 2004). Of the three species included in this study, $\mathrm{T}$. graeca is a herbivore in which ingestion of faeces is considered unusual (Andreu et al., 2000), while the two turtles mainly feed in water, where the risk of Salmonella infection should be high. Thus, we consider that the high incidence of Salmonella that we found in tortoises might not be originated only via oral ingestion. Cloacal transmission might be a mechanism of transmission among individuals, especially as individual females are frequently mounted for copulation by different males during the breeding season (Roques et al., 2004). Frequent mounting has also been reported for aquatic European turtles, E. orbicularis, although the dominance strategy reported for some males suggests that this species (Rovero et al., 1999) would have lower frequency of cloacal contact among individuals than T. graeca. The lower frequency of sexual encounters in aquatic than 
in terrestrial turtles might explain their corresponding lower incidence of Salmonella infections.

In general, the aquatic medium is considered a favourable environment for transmission of Salmonella (Polo et al., 1999; Baudart et al., 2000). However, some terrestrial reptiles have high infection rates of Salmonella (Greenberg et al., 1976; Burnham et al., 1998), and our results demonstrate that, within the same study area, aquatic turtles are less prone to Salmonella infection than the terrestrial species. It may be explained by the lower persistence of the bacteria in organisms living in aquatic medium where they are washed from skin and cloaca, while in terrestrial habitats they persist longer and are directly transmitted among individuals.

\section{Acknowledgements}

We thank A. Portheault, M. Florencio, X. Ruiz, A. Andreu, E. Ortiz, A. Herrero and J.L. Ayala for their field assistance, and to R. Andrews for her comments to the manuscript. J. Hidalgo-Vila was financed by I3P-CSIC research grant. This study was supported by Consejería Medio Ambiente-Junta de Andalucía (UE cofinanciated project).

\section{References}

Abalem de Sá, I.V., Solari, C.A., 2001. Salmonella in brazilian and imported pet reptiles. Braz. J. Microbiol. 32, 293-297.

Andreu, A.C., Díaz-Paniagua, C., Keller, C., 2000. La tortuga mora (Testudo graeca L.) en Doñana. Monografías de Herpetología, vol. 5. Asociación Herpetológica Española, Barcelona.

Baudart, J., Lemarchand, K., Brisabois, Lebaron, P., 2000. Diversity of Salmonella strains isolated from the aquatic environment as determined by serotyping and amplification of the ribosomal DNA spacer regions. Appl. Environ. Microbiol. 66, 1544-1552.

Briones, V., Téllez, S., Goyache, J., Ballesteros, C., Lanzarot, M.P., Domínguez, L., Fernández-Garayzábal, J., 2004. Salmonella diversity associated with wild reptiles and amphibians in Spain. Environ. Microbiol. 6, 868-871.

Bronikowski, A.M., Brennett, A.F., Lenski, R.E., 2001. Evolutionary adaptation to temperature. VIII. Effects of temperature on growth rate in natural isolates of Escherichia coli and Salmonella enterica from different thermal environments. Evolution 55, 33-40.

Burnham, B.R., Atchley, D.H., DeFusco, R.P., Ferris, K.E., Zicarelli, J.C., Lee, J.H., Angulo, F.J., 1998. Prevalence of faecal shedding of Salmonella organisms among captive green iguanas and potential public health implications. JAVMA 213, 48-50.
Chiodini, R.J., Sundberg, J.P., 1981. Salmonellosis in reptiles: a review. Am. J. Epidemiol. 113, 494-499.

Corrente, M., Madio, A., Friedrich, K.G., Greco, G., Desario, C., Tagliabue, S., D’Incau, M., Campolo, M., Buonavoglia, C., 2004. Isolation of Salmonella strains from reptile faeces and comparison of different culture media. J. Appl. Microbiol. 96, 709-715.

Feeley, J.C., Treger, M.D., 1969. Penetration of turtle eggs by Salmonella braenderup. Public Health Rep. 84, 156-158.

Fritz, U., 2001. Handbuch der Reptilien und Amphibien Europas. Schildkröten (Testudines) (Bataguridae, Testudinidae, Emydidae). Band 3/IIIA. Aula Verlag, Wiesbaden.

Geue, L., Löschner, U., 2002. Salmonella enterica in reptiles of German and Austrian origin. Vet. Microbiol. 84, 79-91.

Greenberg, Z., Sklut, O., Bergner-Rabinowitz, S., Sechter, I., Cahan, D., Gerichter, Ch.B., 1976. Salmonella and Arizona from snakes in the Judean desert. Ann. Microbiol. 127, 383-390.

Kaufmann, F., 1966. The Bacteriology of Enterobacteriaceae. Munksgaard, Copenhagen.

Lynch, M., Daly, M., O’Brien, B., Morrison, F., Cryan, B., Fanning, S., 1999. Salmonella tel-el-kebir and terrapins. J. Infect. 38, 182-184.

Mermin, J., Hoar, B., Angulo, F.J., 1997. Iguanas and Salmonella marina infection in children: a reflection of the increasing incidence of reptile-associated salmonellosis in the United States. Pediatrics 99, 399-402.

Mermin, J., Hutwagner, L., Vugia, D., Shallow, S., Daily, P., Bender, J., Koehler, J., Marcus, R., Angulo, F.J., 2004. Reptiles, amphibians, and human Salmonella infection: a population-based, case-control study. Clin. Infect. Dis. 38, S253-S261.

Millan, J.M., Purdie, J.L., Melville, L.F., 1997. Public health risks of the flesh farmed crocodiles. Rev. Sci. Tech. Off. Int. Epiz. 16, 605-608.

Mitchell, M.A., Shane, S.M., 2000. Preliminary findings of Salmonella spp. in captive green iguanas (Iguana iguana) and their environment. Prev. Vet. Med. 45, 297-304.

Ozsan, K., Aksoycan, N., Fazli, A., Aktan, M., Say, S., Daglioglu, H., 1973. Les salmonelles isolées des animaux sauvages capturés dans les différentes régions de la Turquie. Bulletin de la Société de Pathologie Exotique 66, 600-603.

Pasmans, F., De Herdt, P., Chasseur-Libotte, M.L., Ballasina, D.L., Haesebrouck, F., 2000. Occurrence of Salmonella in tortoises in a rescue centre in Italy. Vet. Rec. 146, 256-258.

Pasmans, F., De Herdt, P., Haesebrouck, F., 2002. Presence of Salmonella infections in freshwater turtles. Vet. Rec. 150, 692-693.

Pasmans, F., Martel, A., Boyen, F., Vandekerchove, D., Wybo, I., Van Immerseel, F., Heyndrickx, M., Collard, J.M., Ducatelle, R., Haesebrouck, F., 2005. Characterization of Salmonella isolates from captive lizards. Vet. Microbiol. 110, 285-291.

Polo, F., Figueras, M.J., Inza, I., Sala, J., Fleisher, J.M., Guarro, J., 1999. Prevalence of Salmonella serotypes in environmental waters and their relationships with indicator organisms. A. Van Leeuw. 75, 285-292.

Richards, J.M., Brown, J.D., Kelly, T.R., Fountain, A.L., Sleeman, J.M., 2004. Absence of detectable Salmonella cloacal shedding in free-living reptiles on admission to the wildlife center of Virginia. J. Zoo Wildl. Med. 35, 562-563. 
Rodgers, G.L., Long, S.S., Smergel, E., Dampier, C., 2002. Salmonella infection associated with a pet lizard in siblings with sickle cell anemia: an avoidable risk. J. Pediatr. Hematol. Oncol. 24, 75-76.

Roques, S., Díaz-Paniagua, C., Andreu, A.C., 2004. Microsatellite markers reveal multiple paternity and sperm storage in the Mediterranean spur-thighed tortoise, Testudo graeca. Can. J. Zool. 82, 153-159.

Roszak, D.B., Grimes, D.J., Colwell, R.R., 1984. Viable but nonrecoverable stage of Salmonella enteriditis in aquatic systems. Can. J. Microbiol. 30, 334-338.

Rovero, F., Lebboroni, M., Chelazzi, G., 1999. Aggressive interactions and mating in populations of the european pond turtle Emys orbicularis. J. Herpetol. 33, 258-263.

Thomas, A.D., Forbes-Faulkner, J.C., Speare, R., Murray, C., 2001. Salmonelliasis in wildlife from Queensland. J. Wildl. Dis. 37, 229-238.
Torfoss, D., Abrahamsen, T.G., 2000. Salmonella infection from turtles. Tidsskr. Nor. Laege. 120, 3670-3671.

Unicomb, L., Bird, P., Dalton, C., 2003. Outbreak of Salmonella Potsdam associated with salad dressing at a restaurant. Commun. Dis. Intell. 27, 508-512.

Usera, M.A., Aladueña, A., Díaz, R., de la Fuente, M., Cerdán, P., Gutierrez, R., 1999. Análisis de las cepas de Salmonella spp. aisladas de muestras de origen no humano en España en el año 1998. Instituto de Salud Carlos III. Boletín Epidemiológico Semanal. 7, 93-104.

Woodward, D.L., Khakhria, R., Johnson, W.M., 1997. Human salmonellosis associated with exotic pets. J. Clin. Microbiol. 35, 2786-2790.

Wuthe, H.H., Rohde, R., Aleksic, S., Schubert, C., Wuthe, S., 1979. Salmonella in free living snakes of Northern Germany (author's translation). Zentralbl. Bakteriol. 243, 412-418. 